\title{
Coastal Wind Measurements and Power Assessment Using a LIDAR on a Pier
}

\author{
Felipe Barros Nassif ${ }^{1}$, Felipe Mendonça Pimenta ${ }^{2}$ (D), Carla de Abreu D'Aquino ${ }^{3}$, \\ Arcilan Trevenzoli Assireu ${ }^{4}$, Luis Hamilton Pospissil Garbossa ${ }^{5}$, Júlio César Passos ${ }^{1}$ \\ ${ }^{\text {I}}$ Programa de Pós-Graduação em Engenharia Mecânica, Universidade Federal de Santa \\ Catarina, Florianópolis, SC, Brazil. \\ ${ }^{2}$ Programa de Pós-Graduação em Oceanografia, Universidade Federal de Santa Catarina, \\ Florianópolis, SC, Brazil. \\ ${ }^{3}$ Programa de Pós-Graduação em Energia e Sustentabilidade, Universidade Federal de Santa \\ Catarina, Campus Araranguá, Araranguá, SC, Brazil. \\ ${ }^{4}$ Instituto de Recursos Naturais, Universidade Federal de Itajubá, Itajubá, MG, Brazil. \\ ${ }^{5}$ Empresa de Pesquisa Agropecuária e Extensão Rural de Santa Catarina, Florianópolis, SC, \\ Brazil.
}

Received: 14 December 2018 - Accepted: 20 September 2019

\begin{abstract}
This paper reports the first LIDAR measurements obtained on a fishing pier in Santa Catarina, southern Brazil. A laboratory was built to monitor the vertical structure, time and directional variability of winds in the transitional region between the ocean and the continent. A meteorological station provided pressure, temperature, wind and humidity data. Prevailing winds tend to blow from the NE along the coastline, strongly influenced by the South Atlantic Subtropical High Pressure center. Sea and land breezes had significant amplitude. The offshore wind component (sea breeze) was generally active from 11:00 to 20:00 h; the onshore component (land breeze) from 22:00 to 09:00 h. Weak vertical shear and increasing wind speeds were typically observed in the early afternoon, while stronger shear and the highest wind speeds tend to occur in the late afternoon. Winds profiles from the ocean sector were usually more intense and less sheared. The average power of wind turbines was estimated. The local resource is nearly 2.5 times greater than that of a site located $9.3 \mathrm{~km}$ inland. The use of coastal laboratories was demonstrated to be a cost-saving solution for long-term monitoring of the country's wind resources.
\end{abstract}

Keywords: offshore wind energy, coastal pier, LIDAR, remote sensing, Santa Catarina, Brazil.

\section{Medição dos Ventos Costeiros e Avaliação dos Recursos Eólicos Através de um LIDAR sobre um Pier}

\begin{abstract}
Resumo
Este artigo relata as primeiras medições com um LIDAR obtidas sobre uma plataforma de pesca em Santa Catarina. Um laboratório foi construído para monitorar a estrutura vertical e a variabilidade temporal e direcional dos ventos na região de transição entre o oceano e o continente. Uma estação meteorológica forneceu registros de pressão, temperatura, ventos e umidade. Ventos de NE sopram dominantemente ao longo da costa, influenciados pelo centro de Alta Pressão do Atlântico Sul. Brisas marítimas e terrestres apresentaram amplitude significativa. A componente "maral" (brisa marinha) está ativa entre 11:00 e 20:00 e a "terral" (brisa terrestre) entre 22:00 e 09:00. Baixo cisalhamento vertical e aumento da velocidade do vento são observados no princípio da tarde, enquanto um forte cisalhamento vertical e ventos mais intensos são observados no fim da tarde. O perfil dos ventos do setor oceânico foi mais intenso e menos cisalhado
\end{abstract}

Autor de correspondência: Felipe Mendonça Pimenta, felipe.pimenta@ufsc.br. 
verticalmente. A potência média das turbinas eólicas modernas foi estimada. O potencial encontrado é cerca de 2,5 vezes maior comparado a um ponto continental localizado a $9,3 \mathrm{~km}$ de distância. $\mathrm{O}$ uso de laboratórios costeiros demonstrou ser uma solução econômica viável para o monitoramento de longo prazo dos recursos eólicos do país.

Palavras-chave: energia eólica offshore, pier costeiro, LIDAR, sensoriamento remoto, Santa Catarina, Brasil.

\section{Introduction}

By the end of 2018, wind power attained $14.71 \mathrm{GW}$ of total installed capacity in Brazil, provided by 583 farms (Abeeolica, 2018). Wind currently represents $9.0 \%$ of the country's generation, and there are sufficient resources to increase its contribution. Continental wind resources, initially estimated at $143.5 \mathrm{GW}$ at the height of $50 \mathrm{~m}$ (Amarante et al., 2001), were updated to $880 \mathrm{GW}$ at the height of $100 \mathrm{~m}$ (FAPESP, 2016). The offshore potential is also very large, around $1300 \mathrm{GW}$ for wind turbines installed on the continental shelf up to $100 \mathrm{~m}$ depth (Silva et al., 2016, Pimenta et al., 2019).

Although many wind farms are located over land in coastal areas and in shallow regions offshore, wind measurements tend to be scarce in these regions. Observational networks need to be improved in order to provide multilevel information and wind measurements at turbine hub height and above. This type of information is necessary to accurately describe dynamic coastal processes such as sea breezes, low-level jets, and other land-air-ocean interactions (Archer et al., 2014). Wind observations in the coastal zone are also crucial for resource estimation, validation of numerical models, micro-siting of turbines and the optimization of wind farms (Manwell et al., 2010).

In the United States, Europe and Japan, remote wind profiling with LIDAR (Light Detection and Ranging) has been extensively used in former years, either complementing or replacing meteorological masts. Shimada et al. (2014) monitored winds with a LIDAR installed over a research pier on the coast of Japan. Bischoff et al. (2015) installed a LIDAR on a pier in Barcelona for comparison with another installed on a buoy. LIDARs have been tested in comparison with meteorological towers equipped with anemometers from Riso DTU test facility in northern Denmark (Kindler et al., 2009). LIDARs have also been installed on fixed offshore platforms (Peña et al., 2009).

Thus far, few studies have taken LIDAR observations made in Brazil into consideration. A pioneer study monitored winds with a Windcube LIDAR on the coast of Pedra do Sal (Santos et al., 2015; Sakagami et al., 2015). Salvador et al. (2016) compared Weather Research and Forecasting (WRF) model simulations with a coastal LIDAR, a SODAR and radiosondes. Nassif (2017) mounted a LIDAR on a buoy to profile the winds of the Furnas hydroelectric reservoir. To the best of the author's knowledge, however, no studies have taken coastal measurements in the transitional zone between the ocean and the continent into consideration.
While the installation of offshore towers is expensive, varying from 2.5 to 10 million dollars (Wissemann, 2009; Hasager et al., 2013; Howe, 2014), platforms and fishing piers may serve as versatile alternatives for the observation of ocean winds. Besides having low operating costs, they provide easy access for maintenance, power for instruments and protection against vandalism.

The present study describes the first measurements performed with a LIDAR wind profiler installed $250 \mathrm{~m}$ from the coast on a fishing pier off southern Santa Catarina state, located in the southern region of Brazil. A small laboratory was built to provide support, protection against lightning and power supply for the LIDAR. The so-called "Ocean and Atmosphere Observation Base" (BOOA), was also equipped with a meteorological tower.

The first five months of LIDAR measurements between heights of 20 and $210 \mathrm{~m}$ will be described in this article. A comparison of the LIDAR with the sonic anemometer will be presented, along with the general characteristics of the wind profile. Winds' temporal and directional variability will be explored, highlighting the importance of the sea breeze and demonstrating the distinction between the winds of the land and ocean sectors. The capacity factor and production of modern wind turbines will also be evaluated.

\section{Material and Methods}

\subsection{Ocean and atmosphere observation base}

The Ocean and Atmosphere Observation Base (Base de Observação do Oceano e Atmosfera, BOOA) is an experimental laboratory constructed on the Entremares Fishing Pier of the town of Balneário Arroio do Silva, Santa Catarina (Fig. 1a). The BOOA is located near the end of the pier, $250 \mathrm{~m}$ from the beach, at latitude $28^{\circ} 57^{\prime} 46.670^{\prime \prime} \quad \mathrm{S}$ and longitude $49^{\circ} 22^{\prime} 48.620^{\prime \prime} \mathrm{W}$ (Fig. 1b).

The internal dimensions of the laboratory are $2.5 \mathrm{~m} \mathrm{x}$ $2.5 \mathrm{~m}$ with a height of $2.5 \mathrm{~m}$ (Fig. 2). The parameters currently monitored are: air temperature, wind speed and direction, relative humidity and air pressure. The BOOA is equipped with its own electrical system for the operation of the equipment. A 10-meter tall, freestanding meteorological mast and a LIDAR wind profiler are installed on the roof of the laboratory (Figs. 2a,b), along with a lightning rod to protect against electrical discharges. The met station has an SDITH-01 dual base thermohygrometer with a cover to protect against sunlight, a Thies first class cup anemometer and a Young 81000 3D sonic anemo- 


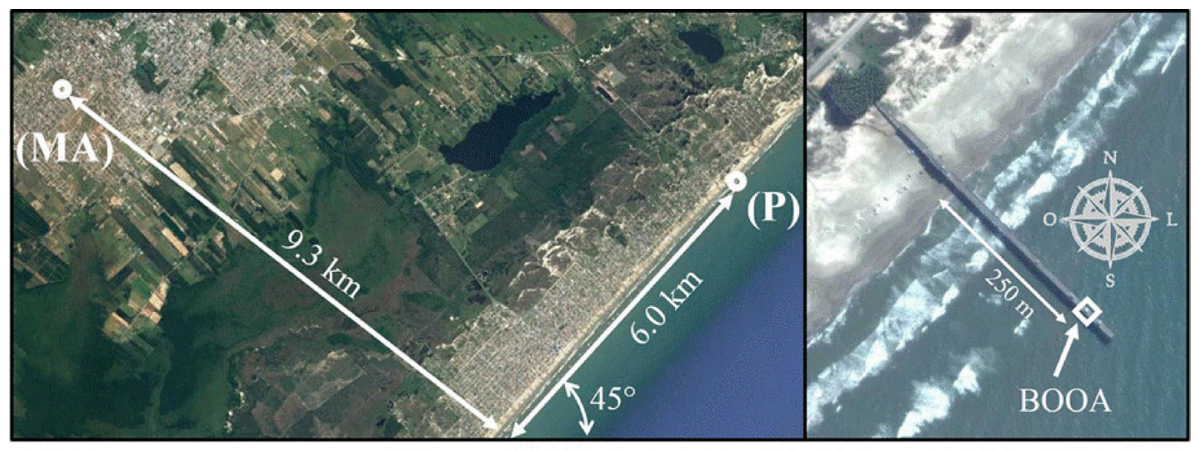

(a)

(b)

Figure 1 - (a) Geographical position of the fishing pier (P) on the coast of Balneário Arroio do Silva, Santa Catarina state, Brazil. The Federal University of Santa Catarina Campus of Mato Alto (MA) is indicated. (b) Location, orientation and length of the Ocean and Atmosphere Observation Base (BOOA). The lie of the coast is inclined at approximately $45^{\circ}$ from true east.

meter (Fig. 2c). A data logger, modem and a GPS for time synchronization are installed inside the lab.

The LIDAR is a Zephir ZP300. The equipment provides multilevel measurements of winds, information that is crucial for resource assessment. This was the first time that a LIDAR was installed in the southern state of Santa
Catarina, a region with significant wind resources (Pimenta et al., 2008, Silva et al., 2016, Pimenta et al., 2019, Correa, 2018) and characterized by important oceanographic and meteorological processes (Moller et al., 2008, Pianca et al., 2010, Matano et al., 2014, Reboita et al., 2017). In particular, the first South Atlantic Hurri-

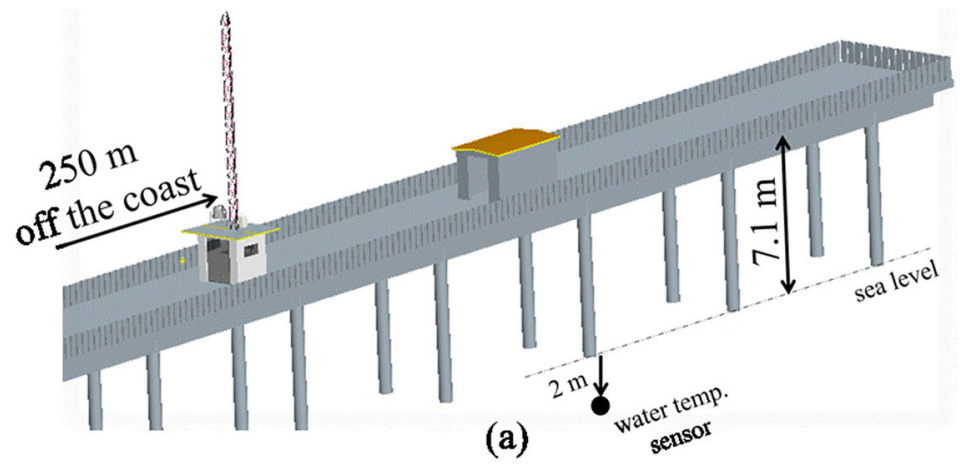

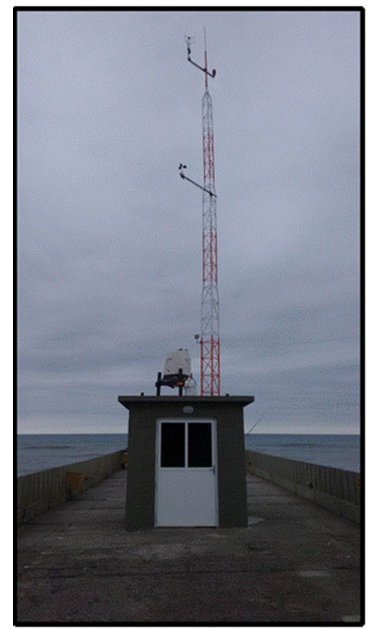

(b)

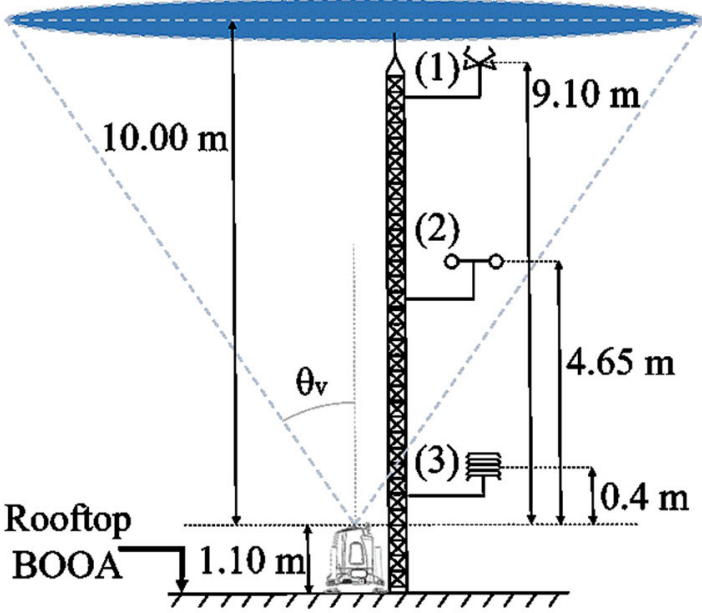

(c)

Figure 2 - (a) The Ocean and Atmosphere Observation Base (BOOA) in a 3D computational model. (b) Laboratory after construction and installation of equipment in December 2016. (c) Arrangement of meteorological instruments above the laboratory's rooftop: (1) sonic anemometer, (2) cup anemometer, and (3) thermohygrometer. The LIDAR is located beside the mast. Heights shown in this figure are measured from the laboratory rooftop, which is $9.6 \mathrm{~m}$ above mean sea level. The LIDAR's first measurement is around $20 \mathrm{~m}$ above mean sea level. 
cane, made landfall in late March 2004 in this region (Mctaggart-Cowan et al., 2006, Vianna et al., 2010).

Instruments were installed on December $10^{\text {th }}, 2016$ and the time series analyzed in this article has five months of data, ending on May 15, 2017. The average height of the pier's deck above the water surface is $7.1 \mathrm{~m}$, so that the LIDAR is located nearly $9.6 \mathrm{~m}$ above the water surface (Figs. 2a,c). Table 1 reports the heights of the instruments relative to the mean sea level.

\subsection{Zephir LIDAR}

Zephir ZP300 is a wind profiler with continuous laser emission. This characteristic combines simplicity with high sensitivity at the measurement heights that are relevant for wind power (Pitter et al., 2013). Wind speeds are measured by inferring the velocity of particles and aerosols carried by the wind. The infrared laser beam scans the atmosphere and a small part of the laser is reflected by particles. A receptor system interprets the return signal. The speed of particles (aerosols) dispersed in the atmosphere is obtained from the Doppler effect.

The LIDAR system operates in the near infrared band $(\sim 1560 \mathrm{~nm})$. The laser focus emitted at the various heights determined by the user forms a cone at $30^{\circ}$ to the vertical (Fig. 2c). At each height, 50 measurements are taken around a circle drawn by the laser beam (i.e. on the cone edge). This scan provides measurements of the line of sight velocity $V_{L O S}$ (along the laser beam). The relation of $V_{L O S}$ to the horizontal $U$ and vertical $w$ velocities is described by Peña et al. (2009) and Li and Yu (2017):

$$
V_{L O S}=\left|U \cos \left(\phi-\phi_{d}\right) \sin \theta_{v}+w \cos \theta_{v}\right|
$$

where $\phi$ is the instantaneous azimuth angle, $\phi_{d}$ is the wind direction, and $\phi_{v}$ is the angle of the cone to the vertical. Both wind speed and direction are assumed to be uniform within the control volume ring. Based on this equation, it is possible to find $U, w$ and $\phi_{d}$ by the least squares method applied to the $V_{L O S}$ measurements ( $\mathrm{Li}$ and $\mathrm{Yu}, 2017$ ).

Zephir can take measurements at heights from 10 up to $300 \mathrm{~m}$. In this study, the measurements were programmed for $10,20,40,60,80,100,140,160,180$ and $200 \mathrm{~m}$ above the instrument. Because the profiler was mounted on the top of the BOOA, around $10 \mathrm{~m}$ above mean sea level, $10 \mathrm{~m}$ was added to each LIDAR measure-

Table 1 - Height of the meteorological measurements above the mean sea level.

\begin{tabular}{lc}
\hline Instrument & Height above mean sea level $(\mathrm{m})$ \\
\hline 3D Sonic Anemometer & 19.7 \\
Cup Anemometer & 15.2 \\
Thermohygrometer & 11.0 \\
2D Sonic Anemometer & 10.5 \\
LIDAR wind measurement posi- & $20,30,50,70,90,110,150,170$, \\
tions & 190,210 \\
\hline
\end{tabular}

ment height (Table 1). The measurements are performed sequentially, taking slightly longer than 15 seconds to complete a vertical profile.

The control volume does not have constant thickness and increases with height. Its thickness can attain $1.4 \mathrm{~m}$ for measurements at the height of $10 \mathrm{~m}$ and $15.4 \mathrm{~m}$ for $100 \mathrm{~m}$ above the instrument. Within the control volume, the measurements are balanced by a weighted function based on the local atmospheric scattering coefficient, which tends not to vary more than $10 \%$ throughout the measured volume.

The raw output data from the LIDAR include the horizontal and vertical speed components and wind direction. Every 10 min means are calculated from the output data along with the corresponding standard deviations and turbulence intensity. Values with a high degree of uncertainty might occur due to very low wind speeds, partial obstruction of the laser beam, the occurrence of thick fog or very significant precipitation (Zephir Lidar, 2014). These conditions are identified and discarded by the system's firmware and software, so that the corresponding 10min time series have high confidence and do not require any additional user post-processing or filtering. Table 2 shows some other characteristics of the equipment.

\section{Results and Discussion}

In this section, Zephir LIDAR winds are initially compared to the data obtained by the sonic anemometer at the height of $10 \mathrm{~m}$. Next, analyses of the time series and directional variability of winds are presented, along with the statistical and conceptual descriptions of the diurnal cycle. Finally, the productions of modern wind turbines are estimated. All the analyses were performed based on 10-min averages calculated for each of the selected heights.

\subsection{LIDAR vs. sonic anemometer}

The magnitude of the horizontal wind component derived from the Young 81000 sonic anemometer was compared to the LIDAR data at the height of $10 \mathrm{~m}$ from the deflector prism, near $20 \mathrm{~m}$ above the mean sea level.

Table 2 - Technical specifications of the Zephir ZP300 LIDAR.

\begin{tabular}{lc}
\hline Instrument & Technical specification \\
\hline Dimensions & $1.20 \mathrm{~m} \times 1.20 \mathrm{~m} \times 0.85 \mathrm{~m}$ \\
Profiling range & 10 to $300 \mathrm{~m}$ \\
Sampling frequency & $50 \mathrm{~Hz}$ \\
Laser wavelength & $1.55 \times 10^{-6} \mathrm{~m}$ \\
Cone inclination (vertical) & $30^{\circ}$ \\
Weight & $55 \mathrm{~kg}$ \\
Power consumption & $69 \mathrm{~W}$ \\
Voltage (AC/DC) & $120-240 \mathrm{~V} / 12 \mathrm{~V}$
\end{tabular}


The comparison period refers to the 18 days between April 18 and May 5, 2017 (Fig. 3). The correlation obtained was $R=0.989$ with a linear fit given by: $U_{\text {lidar }}=A\left(U_{\text {sonic }}\right)+B$, where $A=0.92$ and $B=0.24$. The LIDAR tends to slightly underestimate the anemometer. The possible shadow of the mast was disregarded in calculating the correlations due to the low occurrence of winds from that specific sector.

Although this comparison was performed at $20 \mathrm{~m}$ height, previous studies compared Zephir LIDAR with tall towers, demonstrating low bias and high correlation coefficients when compared to cup anemometers in different heights (Peña et al., 2009; Hasager et al., 2013; Kindler, 2006). The complementary of drones might be considered whenever towers are absent and anemometer observations are needed (Assireu et al., 2019a,b).

\subsection{Time series}

The time series of wind speeds at the height of $110 \mathrm{~m}$ for the period from December 10, 2016 to May 15, 2017 is depicted in Fig. 4a. The synoptic variation of the wind's magnitude, which oscillates between 3 and $18 \mathrm{~m} \mathrm{~s}^{-1}$ on the typical scale of 3 to 8 days, is clear (Rodrigues et al., 2004). A higher-frequency signal, related to the diurnal variability of the winds, is also noticeable and this will be explored in section 3.4.
The working range of modern wind power turbines would be attained most of the time, as indicated in Fig. 4a. The lower red line represents the cut-in speed (3 to $4 \mathrm{~m} \mathrm{~s}^{-1}$ ) when a turbine starts generating power; the upper red line is the rated speed (12 to $14 \mathrm{~m} \mathrm{~s}^{-1}$ ), or magnitude when the aerogenerator reaches its rated capacity. As can be seen, local winds are within the operational range more than $80 \%$ of the time. The peak magnitude at the height of $110 \mathrm{~m}^{-1}$ was $18.58 \mathrm{~m} \mathrm{~s}^{-1}$ and the mean speed was $5.63 \mathrm{~m} \mathrm{~s}^{-1}$.

The prevailing winds blow from the northeast, a clear manifestation of the South Atlantic Subtropical High Pressure influence in Santa Catarina (Fig. 4b) (Reboita et al., 2010; Silva et al., 2016). The NE winds, however, are frequently disrupted by the passage of extratropical cyclones, which can be identified by the decay of atmospheric pressure and temperature (Fig. 4c) and strong winds from the southern sector (Fig. 4b) (Rodrigues et al., 2004, Reboita et al., 2017). Temperature decreased during the period of measurements, with an average of $24.5^{\circ} \mathrm{C}$ in the summer and $19.7^{\circ} \mathrm{C}$ in the fall (Fig. 4c). The diurnal cycle of temperature presented an amplitude that varied from 3 to $10{ }^{\circ} \mathrm{C}$. The minimum temperature was observed in April $\left(9{ }^{\circ} \mathrm{C}\right)$ and the maximum in March $\left(35^{\circ} \mathrm{C}\right)$.

LIDAR wind speed magnitudes between the heights of 20 and $210 \mathrm{~m}$ are shown in Fig. 4d. A total of 11 LIDAR observations with height are used to compute this

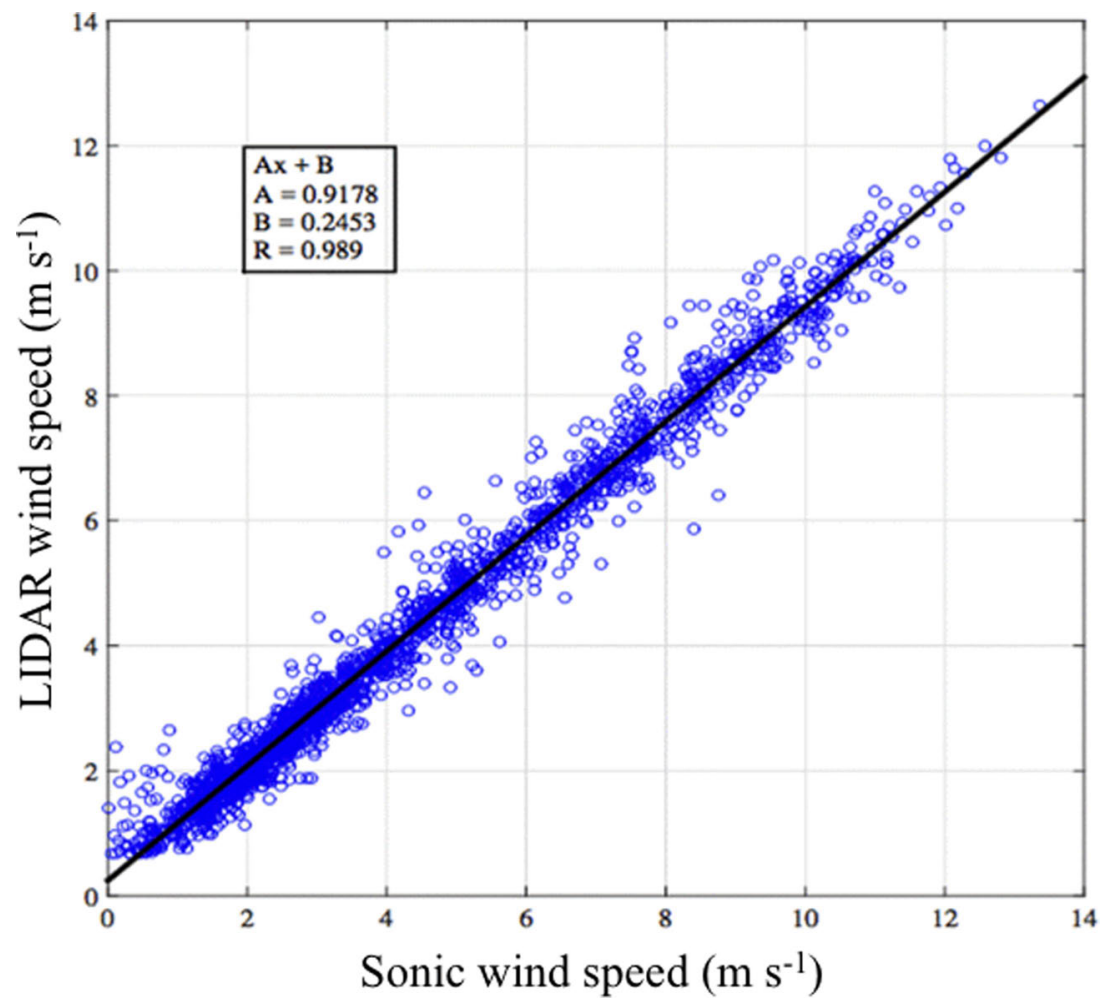

Figure 3 - Correlation between winds measured by the sonic anemometer and the LIDAR measured around $20 \mathrm{~m}$ above mean sea level. The temporal resolution of the dataset is $10 \mathrm{~min}$. 


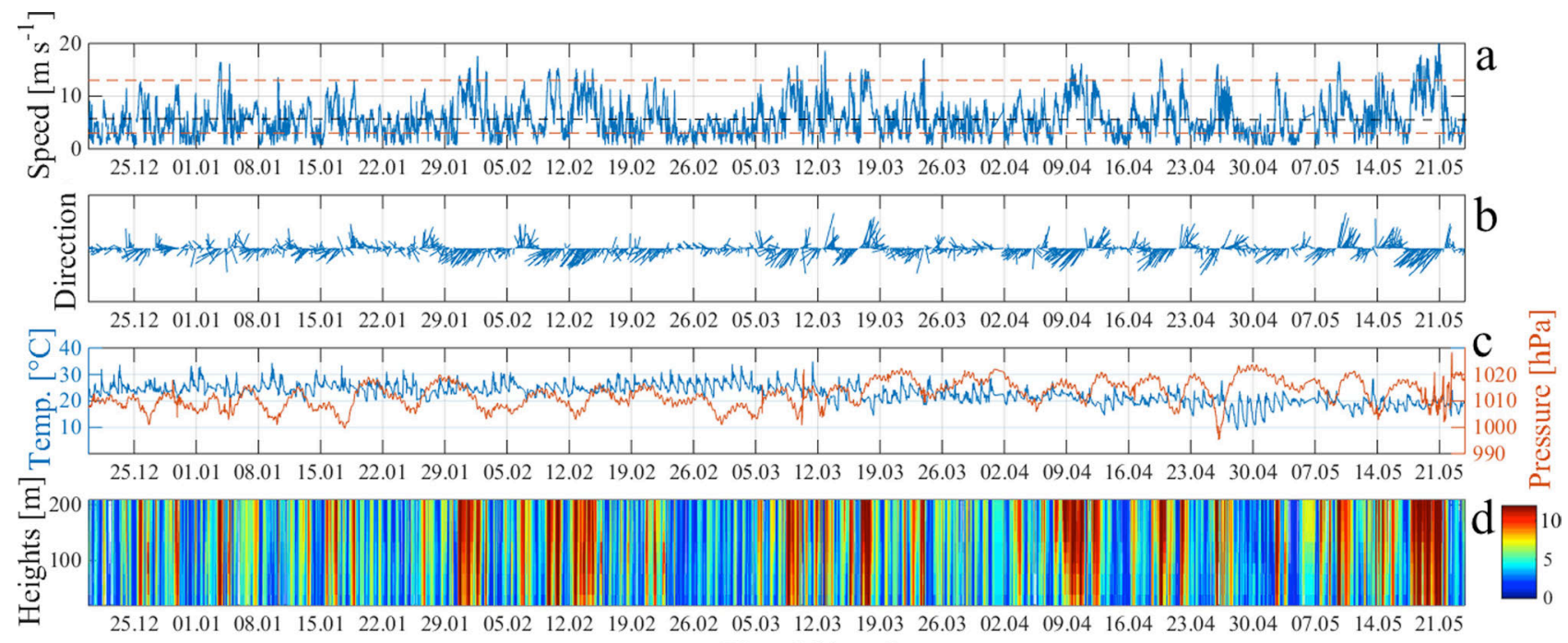
Time [dd.mm]

Figure 4 - Data time series. (a) Wind speed for the height of $110 \mathrm{~m}$ measured by the LIDAR. A black horizontal dashed line represents the mean wind speed of $5.63 \mathrm{~m} \mathrm{~s}^{-1}$. Red lines represent the cut-in and rated wind speeds. (b) wind direction at $110 \mathrm{~m}$, (c) temperature and pressure, (d) magnitude of wind speed based on 11 observations of the LIDAR with height (20 to $210 \mathrm{~m})$. Time is expressed in local time. Colors on panel $\mathrm{d}$ represent wind speed in $\mathrm{m} \mathrm{s}^{-1}$.

graph. The colors represent the wind speed, with red indicating $10 \mathrm{~m} \mathrm{~s}^{-1}$ winds and blue winds below $4 \mathrm{~m} \mathrm{~s}^{-1}$. Intense wind events from both NE and SW directions were observed from Dec. 2016 to May 2017. The directional distribution of winds and their vertical profile structure will be explained in the next subsection.

\subsection{Directional variability}

Directional histograms of winds at $110 \mathrm{~m}$ height above the mean sea level are shown in Fig. 5. Winds blow predominantly from the northeast in December, January and February, with the highest northeasterly occurrence (58.9\%) occurring in February. From March to May the tendency for winds to blow from the S and SW quadrants gains importance. The directional histogram for May depicts a greater influence of the SW quadrant (33.5\%) although this season also had the largest percentage of NE winds with speeds above $12 \mathrm{~m} \mathrm{~s}^{-1}$.

There was a significant distinction of vertical wind profiles according to their wind direction. Figure 6 a illustrates wind speed profiles between 20 and $210 \mathrm{~m}$ height above the mean sea level, averaged for $45^{\circ}$ directional sectors. The most intense winds, nearly $8 \mathrm{~m} \mathrm{~s}^{-1}$ at $110 \mathrm{~m}$, are observed for the NE direction, indicating a dominant influence of the South Atlantic High Pressure system. The average profile was significantly sheared, possibly due to the influence of the topographical elements upwind. Winds from the oceanic sector, E and S, presented 5.7 to $6.5 \mathrm{~m} \mathrm{~s}^{-1}$ magnitudes and weak vertical shear. SE winds are much less frequent and presented low vertical shear and low wind speed magnitudes $\left(4 \mathrm{~m} \mathrm{~s}^{-1}\right)$. The $\mathrm{SW}$ winds, also aligned with the coastline, presented larger magnitudes $\left(6.2 \mathrm{~m} \mathrm{~s}^{-1}\right)$ but lower vertical shear.

Winds from the land sectors $(\mathrm{W}, \mathrm{NW}, \mathrm{N})$ had the lowest average intensity $\left(<4 \mathrm{~m} \mathrm{~s}^{-1}\right)$. $\mathrm{N}$ and $\mathrm{NW}$ presented a deceleration at higher levels at BOOA; the greatest speed for these profiles was observed between 70 and $120 \mathrm{~m}$ height. This deceleration with height might be associated with the breeze circulation, which will be commented on section 3.4 .

Figure $6 \mathrm{~b}$ further summarizes the BOOA wind speed vertical profiles, presenting directional averages for the offshore and onshore sectors. It also compares BOOA data with the LIDAR data collected $9.3 \mathrm{~km}$ inland, at the UFSC Mato Alto Campus (MA) from April 2016 to August 2016 (see Fig. 1b for location).

The solid black line represents the average profile for the BOOA campaign from December 2016 to May 2017. The gray line represents the average wind profile obtained for the UFSC Campus of Mato Alto, between Apr 2016 and Aug 2016 (Fig. 6b). Although the measurement periods are different, the profiles illustrate the importance of the surrounding terrain for the airflow. A marked difference in the winds' magnitude and shear is observed. BOOA winds, either from the oceanic (blue dashed line) or continental sector (green dashed line), were stronger than those at the continental site located $9.3 \mathrm{~km}$ inland. BOOA average winds were also less sheared than those of the Mato Alto observations.

Winds from the continental sector at BOOA were weaker at $100 \mathrm{~m}$ height $\left(4.7 \mathrm{~m} \mathrm{~s}^{-1}\right)$ and presented greater vertical shear, in agreement with the results of Shimada et al. (2014) for a pier off the coast of Japan. BOOA 

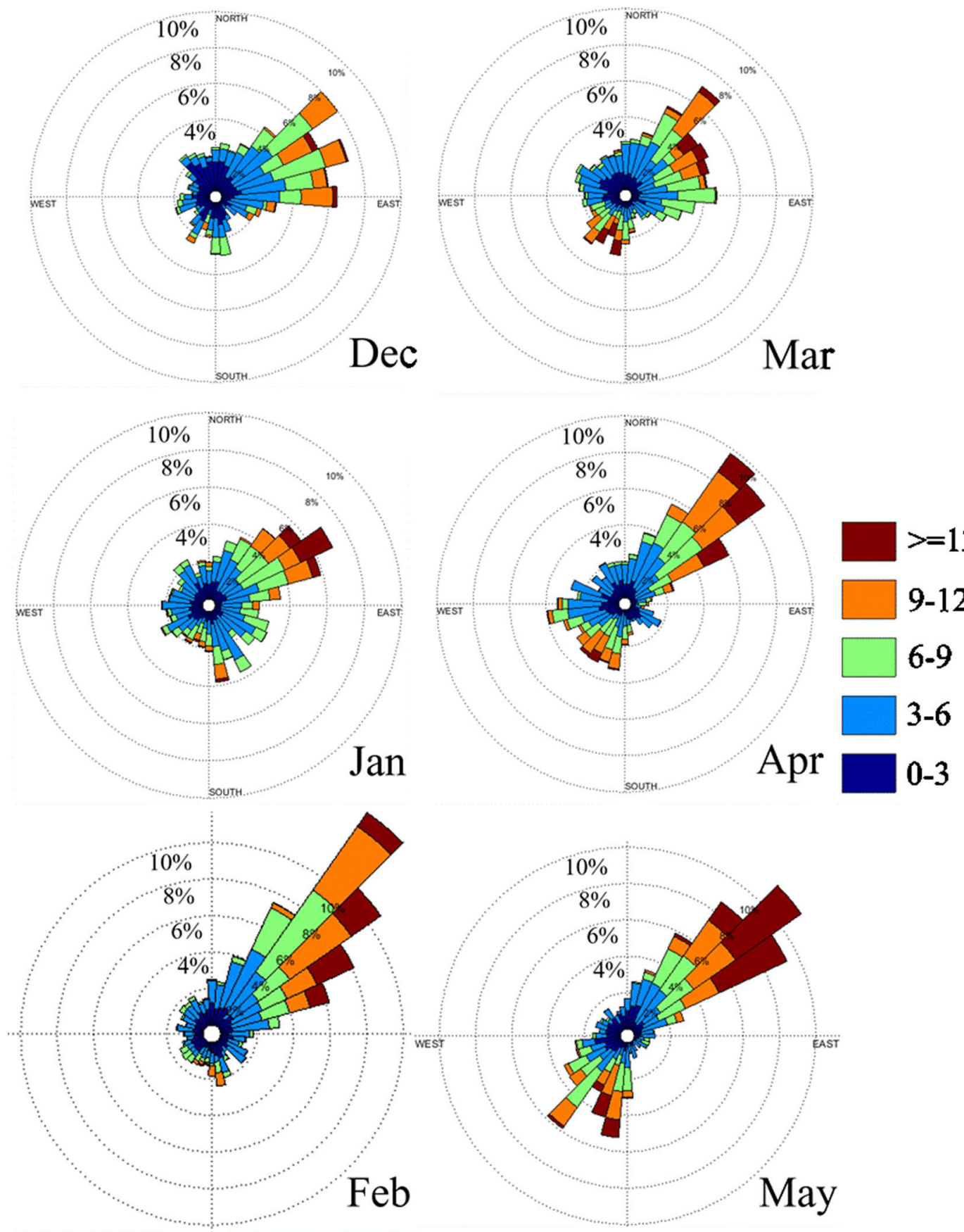

Figure 5 - Wind rose for December 2016 to May 2017. Bars indicate the direction from which the wind blows, N $\left(0^{\circ}\right), \mathrm{E}\left(90^{\circ}\right), \mathrm{S}\left(180^{\circ}\right)$ and W $\left(270^{\circ}\right)$. The percentage scale indicates wind occurrence at $2 \%$ velocity intervals. The color scale indicates wind speed $\left(\mathrm{m} \mathrm{s}^{-1}\right)$ classes.

winds from the offshore sector presented less vertical shear and higher wind speeds $\left(6.7 \mathrm{~m} \mathrm{~s}^{-1}\right)$ at the height of $110 \mathrm{~m}$. The deceleration from the offshore sector above $150 \mathrm{~m}$ height might be due to the breeze return circulation (Miller et al., 2003; Sakagami et al., 2015). Mato Alto is relatively close to the coast $(9.3 \mathrm{~km})$ and presumably subject to the influence of the breeze, but its sector-averaged profile does not illustrate a deceleration with height (Fig. 6b).
A brief analysis of the LIDAR turbulence intensity (TI) presents values of $9.7 \%$ for the offshore sector, $16.2 \%$ for the onshore and an overall average of $12.9 \%$ at the height of $20 \mathrm{~m}$. Here the turbulence intensity is calculated from $T I=\sigma_{u} / \bar{U}$, where $\bar{U}$ is the mean horizontal velocity and $\sigma_{u}$ is its standard deviation for the 10-min intervals.

These $T I$ values are probably underestimated, as conically scanning LIDAR tend to compute nearly $80 \%$ of the standard deviation actually measured by anemometers. 


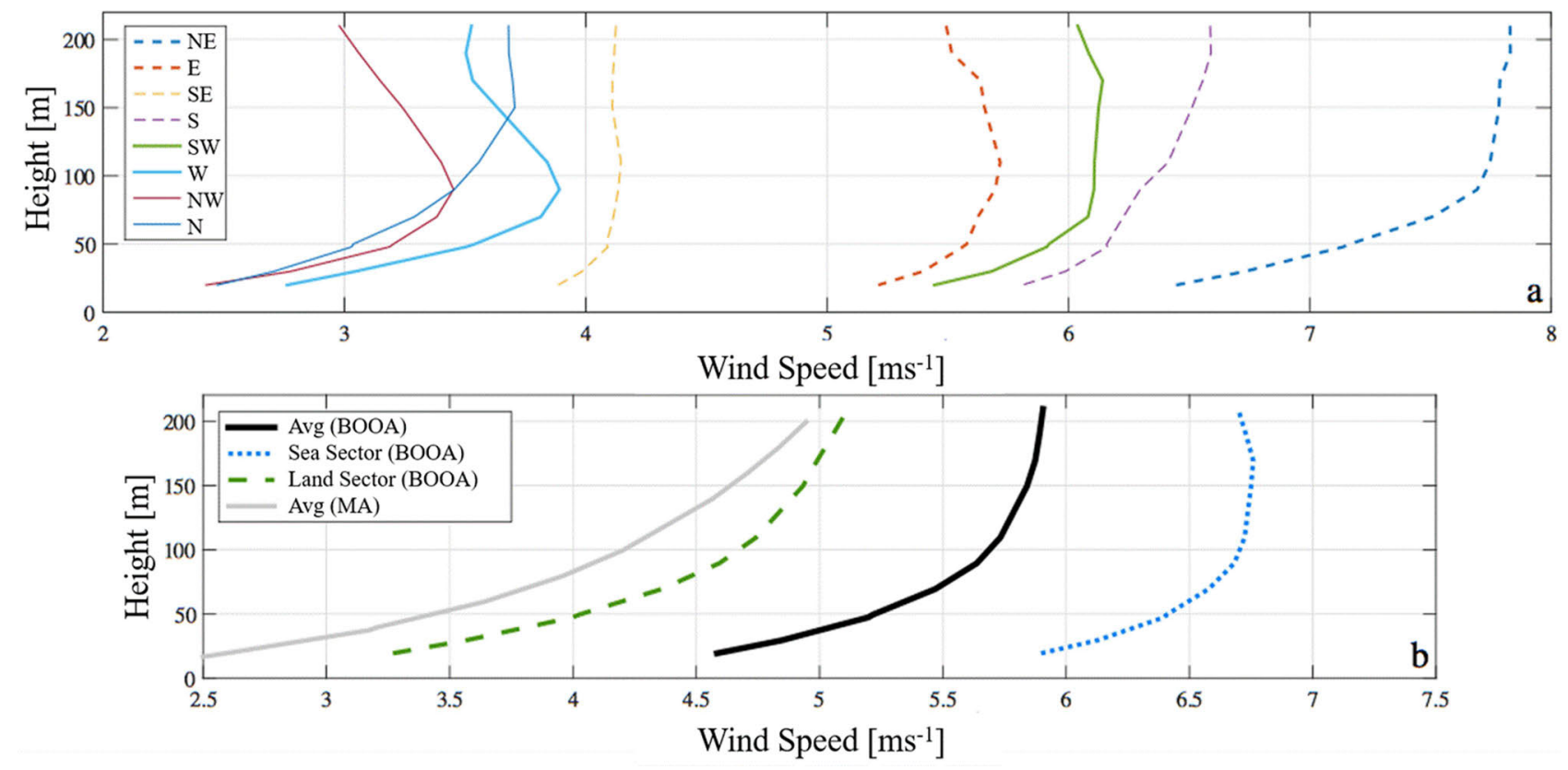

Figure 6 - Profile of speeds subdivided into directional sectors. (a) Profiles for 8 sectors of $45^{\circ}$ and (b) Ocean sector $\left(45^{\circ}\right.$ to $225^{\circ}$ clockwise), land sector ( $45^{\circ}$ to $225^{\circ}$ anticlockwise). Average profiles for BOOA (Dec 2016 to May 2017) and for UFSC Mato Alto (Apr 2016 to Aug 2016) are indicated by the black and gray lines respectively. BOOA and UFSC Mato Alto locations are indicated in Figure 1a.

This happens because scanning LIDAR cannot resolve turbulence structures with length scales smaller than the circle described by the laser (Wagner et al., 2009, Peña et al., 2009). Therefore, corrected estimates of turbulence intensity $T I_{C}=T I / 0.8$, are around $12.1 \%$ for the offshore sector, $20.2 \%$ for the onshore sector and $16.1 \%$ as overall average for BOOA. For purposes of comparison, TI measured by an anemometer on the complex terrain of Santa Catarina Island showed $T I=20.1 \%$ at $20 \mathrm{~m}$ (Santos, 2014).

\subsection{Diurnal variability}

Differences between the ocean and land temperatures in coastal regions generate substantial variations in the pressure field, inducing the breeze circulation (Helmis et al., 1987; Abbs and Physick, 1992; Miller et al., 2003). Here we demonstrate that the diurnal variability observed at BOOA can be described as a superposition of the breeze circulation with the prevailing NE winds.

Winds diurnal variability was explored calculating their average direction and magnitude as functions of time. The results have been summarized in Fig. 7, where a cartoon helps to illustrate the changes of winds relative to the coastline. The cartoon depicts the land- and sea breeze components, as well as the prevailing (large-scale) NE winds (Figs. 7a and b). Directional and wind speed variations are respectively shown in Figs. $7 \mathrm{c}$ and $7 \mathrm{~d}$, where the colored lines identify the LIDAR heights, that vary from $20 \mathrm{~m}$ (red) up to $210 \mathrm{~m}$ (dark blue).
During nighttime $(0: 00$ to $06: 00 \mathrm{~h})$, the land is cold and the ocean typically warmer, so that the land breeze tends to blow from the land to the sea (Fig. 7a). The combination of prevailing NE winds with the land breeze component, results in winds blowing from the land or the N-NW sector (Fig. 7a,c). During this time, the lower wind speed magnitudes ( 4 to $6 \mathrm{~m} \mathrm{~s}^{-1}$ ) and the strongest vertical shears (up to $2 \mathrm{~m} \mathrm{~s}^{-1}$ in $190 \mathrm{~m}$ ) were observed (Fig. 7d).

As the land starts to warm up with the solar radiation, the ocean becomes relatively cooler. The land breeze loses its strength; the sea breeze starts to gain importance. Winds change their direction quite abruptly from 08:00 to 12:00 h (Fig. 4c). Winds initially from the NW $\left(-50^{\circ}\right)$ turn clockwise to the easterly direction $\left(100^{\circ}\right)$, as the sea breeze gains importance. Similarly, the observed wind can be represented by the vector sum of a sea breeze with the prevailing large-scale component (Fig. 7b). Between 12:00 and 18:00 $\mathrm{h}$, the sea breeze is more active and winds remain relatively stable from the E sector (Fig. 7c). The strongest wind magnitudes are observed between 15:00 and 17:00 h ( 7.7 $\left.\mathrm{m} \mathrm{s}^{-1}\right)$ (Fig. 7d).

Wind direction start to change again at 18:00 h, when winds gradually veer in the counter-clockwise direction as the sea breeze loses strength and the land breeze gains importance through the night, restarting a new cycle (Fig. 7b). These results illustrate how the breeze induces cross-shore circulation.

Weak vertical shear (less than $1 \mathrm{~m} \mathrm{~s}^{-1}$ in $190 \mathrm{~m}$ ) is generally observed between 10:00 and 14:00 h, presumably when unstable conditions promote vertical con- 

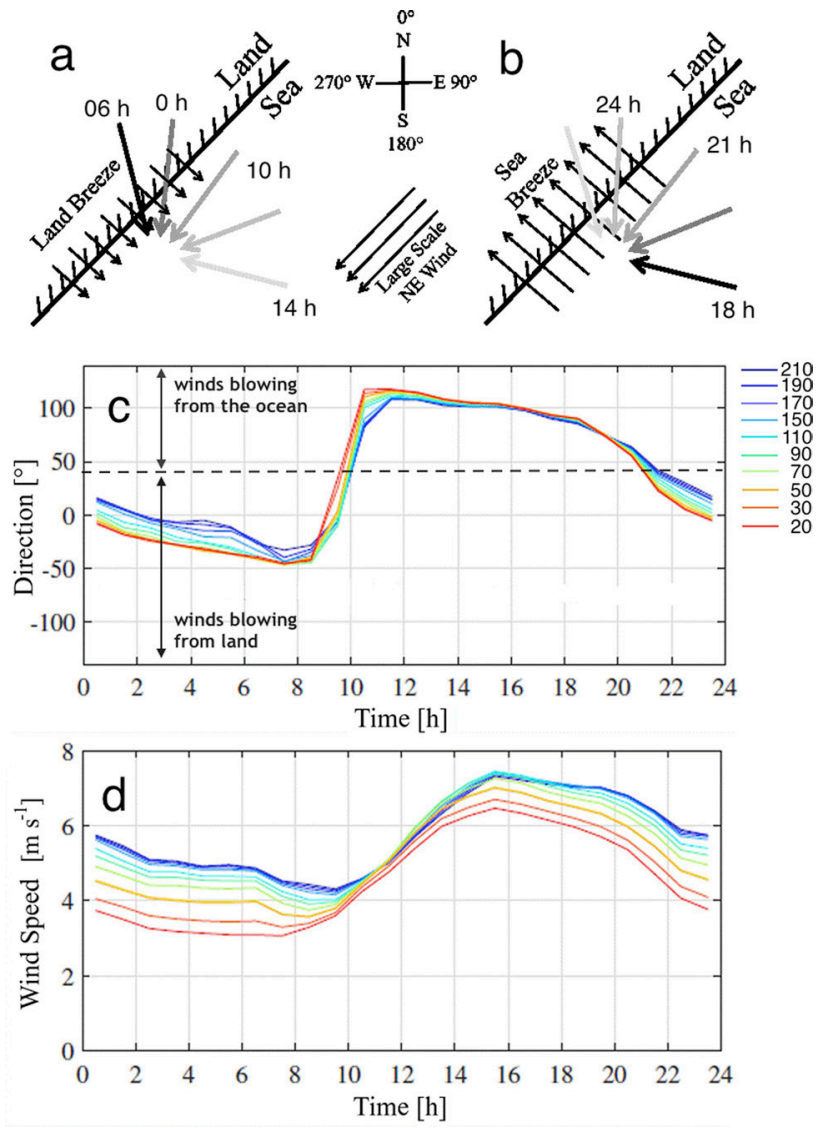

Figure 7 - Diurnal variability of winds. The cartoon illustrates the influence of land breezes (a) and sea breezes (b) modulating the large-scale wind circulation, represented by NE winds. (c) Average wind direction as a function of time of the day. (d) Average wind speed as a function of time. Local time is shown in hours. Directions follow the meteorological convention where $0^{\circ}$ represents winds blowing from the north and $90^{\circ}$ those from the east. Line colors indicate the height above the mean sea level in meters. Red lines represent the measurements at the height of $20 \mathrm{~m}$ and the blue lines at $210 \mathrm{~m}$. vection and more effective transfer of momentum (Fig. 7d). During the night and early morning, the vertical shear is larger $\left(\sim 2 \mathrm{~m} \mathrm{~s}^{-1}\right)$, supposedly due to the tendency for the establishment of neutral to stable conditions (Arya, 2001).

The sea breeze tends to accelerate and turn the winds in lower levels sooner, as verified in Fig. $7 \mathrm{c}$ and d, between 08.00 and 12.00. The deceleration of the winds at a height of $200 \mathrm{~m}$ relative to middle levels (Fig. 7d, 10:00 to $16: 00$ ) is also noteworthy. This happens when winds change from $\mathrm{N}$ to $\mathrm{E}$ direction and might be associated with the breeze return circulation at higher altitudes (Stull, 1988). This type of recirculation can be verified at heights above $200 \mathrm{~m}$ and tends to decelerate the winds in higher levels (Miller et al., 2003; Sakagami et al., 2015).

Lastly, the cold-water upwelling center of Santa Marta Cape at $28.5^{\circ} \mathrm{S}$, extends southwards to $30^{\circ} \mathrm{S}$ during the summer (Möller et al., 2008; Mazzini and Barth, 2013). The presence of colder surface waters can enhance the land to sea temperature differences and potentially strengthen the sea breeze signal, as demonstrated for Cabo Frio from numerical modeling and observations (Franchito et al., 1998; Franchito et al., 2008).

\subsection{Probability distribution}

The Weibull distribution is a function that adequately fits wind speed data (Manwell et al., 2010). This probability distribution function (PDF) is given by:

$$
f_{u}(U)=(c / k)(U / c)^{k-1} e^{(U-c)^{k}}
$$

where $k$ is a non-dimensional shape factor, $c$ is the scale factor $\left(\mathrm{m} \mathrm{s}^{-1}\right)$, and $U$ is the wind speed. Figure 8a illustrates the Weibull probability density function overlaid on the wind speed histogram for the height of $110 \mathrm{~m}$. Of particular note is the greater occurrence of winds between 4 and $6 \mathrm{~m} \mathrm{~s}^{-1}$, around $25 \%$ of the time, with shape factor
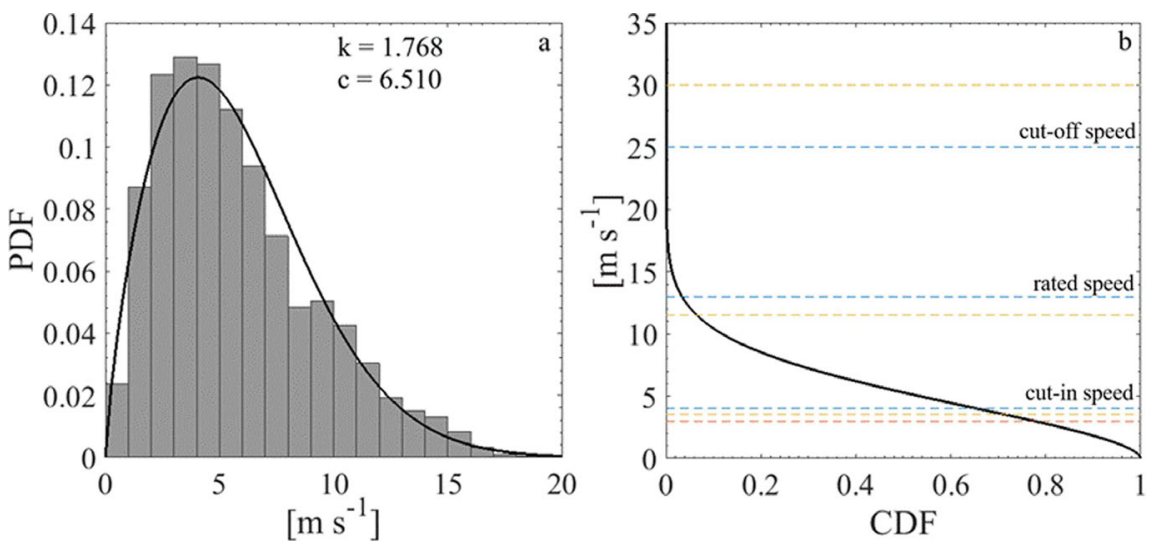

Figure 8 - BOOA LIDAR wind speed probability distributions for the height of $110 \mathrm{~m}$. (a) Probability density function (PDF) and (b) cumulative density function (CDF). Colored dashed lines indicate the limits of operation of Vestas 3.3 (red), Senvion 6.2 (yellow) and Vestas 8.0 (blue) wind turbines. Note that the rated $\left(13 \mathrm{~m} \mathrm{~s}^{-1}\right)$ and cut-off $\left(25 \mathrm{~m} \mathrm{~s}^{-1}\right)$ speeds of Vestas 3.0 and Vestas 8.0 are similar (see Table 3), so that the blue line represents both turbines at this operation speed. 
$k=1.80$ and scale factor $c=6.35$. Speeds greater than $15 \mathrm{~m} \mathrm{~s}^{-1}$ only occurred very rarely.

Figure $8 \mathrm{~b}$ shows the Weibull cumulative distribution function (CDF) with a solid black line. Here the dashed lines indicate the wind speeds in the operational range of three selected wind turbines, the Vestas 3.3 MW, Senvion 6.2 MW and Vestas 8.0 MW (Table 3). The lower lines represent the cut-in speed of each turbine, the middle line the point of maximum generation (rated speed) and the upper lines the cut-out speed, reached only in extreme events. It is possible to note that in the case of the smallest turbine (Vestas 3.3, redline), the system would be in operation $80 \%$ of the time, while the rated speed would be reached almost $10 \%$ of the time. During these five months of observations the cut-out speed was never reached for the turbines selected.

\subsection{Wind power density and turbine generation}

The directional histogram of Fig. 9a represents the distribution of winds at $110 \mathrm{~m}$ height during the entire campaign of measurements, from December 10, 2016 to May 15,2017 . The ocean sector is represented by a background shade of blue, the land sector by a shade of green. The predominance of winds blowing from the NE quadrant, nearly parallel to the coastline is clear. The angle of attack relative to the coastline varies by $\pm 20^{\circ}$ so winds that blow from the ocean (land) display offshore (onshore) characteristics.

Winds with greater magnitudes $\left(>12 \mathrm{~m} \mathrm{~s}^{-1}\right)$ blow more predominantly from the ocean sector (ENE or SSW) and have a significant impact on the wind power density distribution (Manwell et al., 2010):

$$
P_{d}=\frac{1}{N} \sum_{i=1}^{N} \frac{1}{2} \rho_{i} U_{i}^{3} .
$$

here $N$ represents the number of samples, $\rho$ is the air density and $U$ the wind magnitude. Air density can be calculated with the moist-air equation of state $\rho=P /\left(R T_{v}\right), P$ being the atmospheric pressure (Pa) and $R=287,058 \mathrm{~J}$ $\mathrm{kg}^{-1} \mathrm{~K}^{-1}$ the gas constant. $T_{v}$ represents the virtual air temperature (K), $T_{v}=T_{a b s}(1+0.61 w)$, where $T_{a b s}$ is absolute temperature $(\mathrm{K})$ and $w$ the mixing ratio, considered equivalent to the specific humidity (Arya, 2001).

Table 3 - Technical specifications of the turbines Vestas 3.3, Senvion 6.2 and Vestas 8.0.

\begin{tabular}{lccc}
\hline & VE 3.3 & SE 6.2 & VE 8.0 \\
\hline Rated power $(\mathrm{kW})$ & 3300 & 6150 & 8000 \\
Cut-in speed $\left(\mathrm{m} \mathrm{s}^{-1}\right)$ & 3.0 & 3.5 & 4.0 \\
Cut-out speed $\left(\mathrm{m} \mathrm{s}^{-1}\right)$ & 25.0 & 30.0 & 25.0 \\
Rated speed $\left(\mathrm{m} \mathrm{s}^{-1}\right)$ & 13.0 & 11.5 & 13.0 \\
Rotor diameter $(\mathrm{m})$ & 112 & 152 & 164 \\
Area swept $\left(\mathrm{m}^{2}\right)$ & 9852 & 18146 & 21124 \\
\hline
\end{tabular}

$P_{d}$ has units of $\mathrm{W} \mathrm{m} \mathrm{m}^{-2}$ and was estimated from Eq. (3) for winds at 20,50 and $110 \mathrm{~m}$ levels. The results were averaged to 36 directional sectors of $10^{\circ}$ and plotted as polar distributions in Fig. 9b, where the black, blue and red lines indicate the heights of 20,50 and $110 \mathrm{~m}$, respectively.

Despite the presence of winds blowing from all sectors, the greatest average power density was clearly associated with the oceanic sector, more specifically between $50^{\circ}$ and $220^{\circ}$. The average wind power density increases from $300 \mathrm{~W} \mathrm{~m}^{-2}$ at $20 \mathrm{~m}$ height to about $580 \mathrm{~W} \mathrm{~m}^{-2}$ at $110 \mathrm{~m}$ (Fig. 9b).

Winds from the SSW, although less frequent, demonstrated similar mean power densities as winds from the ENE. Winds from the land sector have lesser importance for energy generation.

Figure 10a further illustrates the wind power density time series for the height of $110 \mathrm{~m}$. During strong wind events values up to $3800 \mathrm{~W} \mathrm{~m}^{-2}$ are achieved, but the series' average of $264 \mathrm{~W} \mathrm{~m}^{-2}$, is well below the summer climatologic value of $600 \mathrm{~W} \mathrm{~m}^{-2}$ previously derived from satellite maps (Pimenta et al., 2008; see Fig. 3 of Silva et al., 2016). Although the lengths of LIDAR and satellite records are dissimilar, it is unlikely that power density differences are due to interanual variability. The lower magnitudes observed at BOOA are possibly due to the land's influence, which tends to lower the mean power density.

Figure $9 \mathrm{~b}$ illustrated that the average power density from the ocean sector at BOOA can peak at $560 \mathrm{~W} \mathrm{~m}^{-2}$ (considering winds from $55^{\circ}$ ), which is much closer to the referred satellite estimates of $600 \mathrm{~W} \mathrm{~m}^{-2}$. The differences between LIDAR and satellite estimates are therefore attributed to the spatial variability of ocean winds, which are not resolved by the satellite observations at $25 \mathrm{~km}$ grid resolution. High-resolution numerical modeling $(3 \mathrm{~km})$ suggests that continental roughness and topographic elements located further north, at Cape Santa Marta, generate NE wind wakes. This "coastal boundary layer" presents strong cross-shelf gradients of wind speed and power density (Correa, 2018). It is expected that winds will intensify significantly as an observer moves offshore from the BOOA location.

The practical power generated by modern wind turbines was estimated from three aerogenerators (Table 3 ). Figure 10b illustrates their power-curves, which relate the observed wind speed at the hub height $U\left(\mathrm{~m} \mathrm{~s}^{-1}\right)$ to the turbine power production (MW):

$$
P=f(U)
$$

As substantial variations can occur for the air density, a velocity correction was applied to winds before computing the turbine production (Lu et al., 2009): 

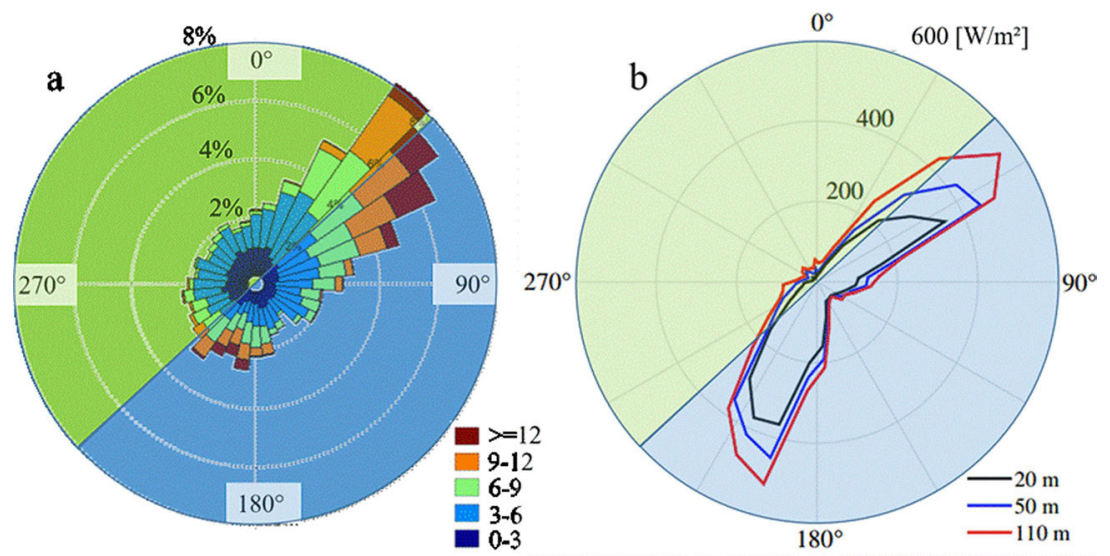

Figure 9 - (a) BOOA wind rose at $110 \mathrm{~m}$, constructed on the basis of the 6-month dataset. Bar length represents the percentage of occurrence and colors the intensity of the wind. (b) Polar graph of the mean power density, computed for sectors of $10^{\circ}$ at heights of 20,50 and $110 \mathrm{~m}$. The land (ocean) sector is indicated by the green (blue) shadow. The power density is calculated with Eq. (3).
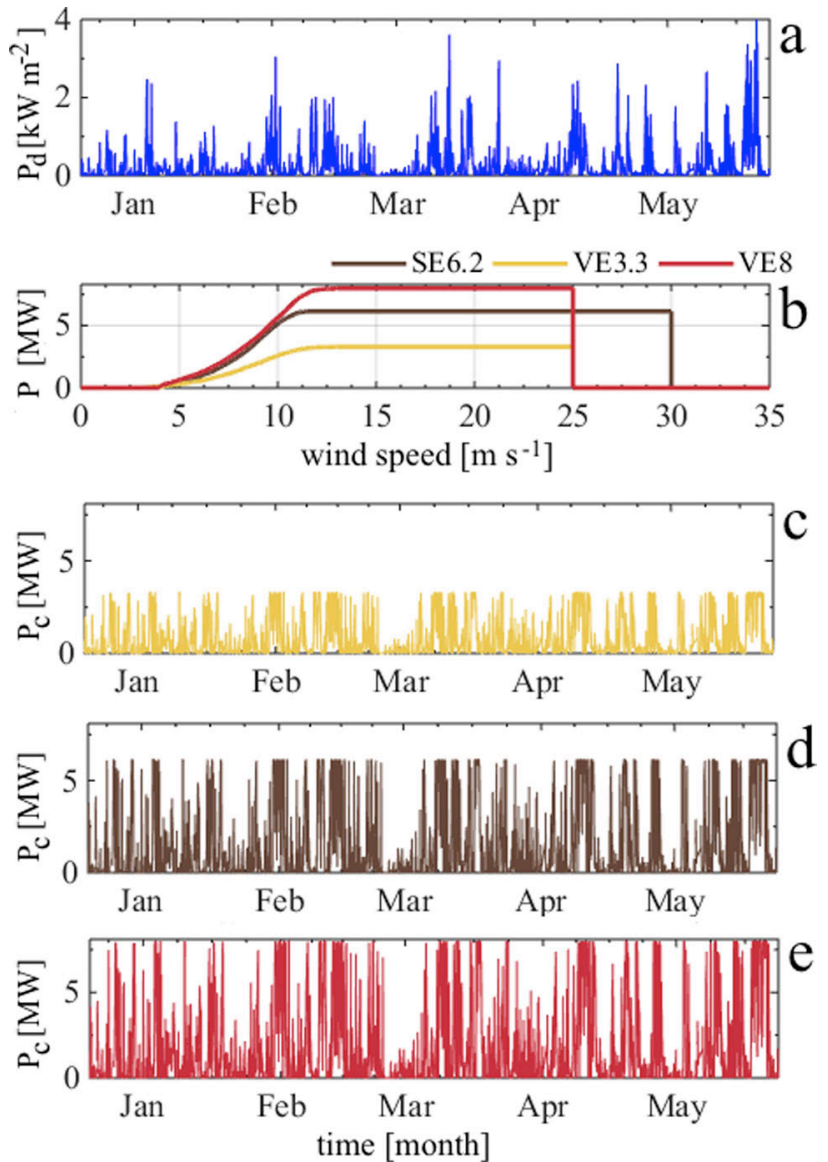

Figure 10 - (a) Wind power density in $\mathrm{kW} \mathrm{m}^{-2}$. (b) Turbine power curves for Vestas 3.3 (VE3.3), Senvion 6.2 (SE6.2) and Vestas 8.0 (VE8.0). Turbines generally start generating power around 3 to $4 \mathrm{~m} \mathrm{~s}^{-1}$ (cut-in speed), achieve full generation capacity around 11 to $13 \mathrm{~m} \mathrm{~s}^{-1}$ (rated speed) and shut-down for protection around 25 to $30 \mathrm{~m} \mathrm{~s}^{-1}$ (cutout speed). (c) Power generated by Vestas 3.3, with an average of $826 \mathrm{~kW}$. (d) Power generated by Senvion 6.2, with an average of $1495 \mathrm{~kW}$. (e) Power generated by Vestas 8.0 with an average of $1823 \mathrm{~kW}$.

$$
U_{c}=U(\rho / 1,225)^{1 / 3}
$$

where $U$ is the measured speed, $\rho$ is the local air density and $U_{c}$ is the corrected speed. Hence, for the practical estimations presented, the turbine power is calculated from Eq. (4) and Eq. (5) as $P_{c}=f\left(U_{c}\right)$. Figures $10 \mathrm{c}$,d,e illustrate the resulting $P_{c}$ time series. Their mean power $\overline{P_{c}}$ is around $1823 \mathrm{~kW}$ for Vestas 8.0, $1495 \mathrm{~kW}$ for Senvion 6.2 and $826 \mathrm{~kW}$ for Vestas 3.3 (Fig. 10).

Table 4 presents the differences of computing the turbine output with and without the velocity correction given by Eq. (5). Estimates were decreased by about $2.5 \%$ after the velocity correction. Monthly averages of wind power density $\left(P_{d}\right)$, capacity factor $(C F)$ and generated power $\left(P_{c}\right)$ between Dec 2016 and May 2017 are summarized in Table 5. Here CF is computed as the ratio of mean turbine power $\overline{P_{c}}$ to the turbine rated capacity $P_{r}$, $C F=\overline{P_{c}} / P_{r}$.

Despite the low output at the beginning of December, the power density, capacity factor, and generated power increase during after March, reached $P_{d}=411 \mathrm{~W}$ $\mathrm{m}^{-2}$ and $1140 \mathrm{~kW}$ for Vestas 3.3 with a $\mathrm{CF}$ of $34.5 \%$ in May. Compared with the national average, these results approximate to Brazil's mean capacity factor between Jan 2018 and May 2018, that varied from 24.6 to $38.7 \%$ (Abeeolica, 2018).

Table 4 - Turbine mean power for Vestas 3.3, Senvion 6.2 and Vestas 8.0. Here $P$ is the power computed with the observed wind speed $U$ provided by the LIDAR and the turbine power curve (Eq. (4)). $P_{c}$ is the power computed with the corrected wind speed $U_{c}$ (Eq. (5)) and the turbine power curve (Eq. (4)). $P_{c}$ estimate accounts for air density variations.

\begin{tabular}{lccc}
\hline & VE 3.3 & SE 6.2 & VE 8.0 \\
\hline$P(\mathrm{~kW})$ & 845 & 1531 & 1868 \\
$P_{c}(\mathrm{~kW})$ & 826 & 1495 & 1823 \\
\hline
\end{tabular}


Table 5 - Mean power density $\left(P_{d}\right)$, capacity factor $(C F)$ and average power $\left(P_{c}\right)$ for the months from December 2016 to May 2017 inclusive.

\begin{tabular}{lcccc}
\hline Month & $P_{d}\left(\mathrm{~W} \mathrm{~m}^{-2}\right)$ & \multicolumn{3}{c}{$\mathrm{CF}(\%) / P_{c}(\mathrm{~kW})$} \\
\cline { 3 - 5 } & & $\mathrm{VE} 3.3$ & $\mathrm{SE6} .2$ & $\mathrm{VE} 8.0$ \\
\hline Dec & 129.52 & $16.5 / 533$ & $15.3 / 947$ & $14.2 / 1142$ \\
Jan & 178.84 & $20.1 / 663$ & $18.8 / 1169$ & $17.9 / 1436$ \\
Feb & 247.05 & $26.0 / 857$ & $25.2 / 1562$ & $23.8 / 1901$ \\
Mar & 226.58 & $23.8 / 785$ & $22.8 / 1411$ & $21.5 / 1723$ \\
Apr & 261.05 & $27.0 / 890$ & $26.2 / 1624$ & $24.6 / 1965$ \\
May & 411.40 & $34.5 / 1140$ & $34.0 / 2105$ & $32.2 / 2578$ \\
Total & 232.40 & $25.0 / 826$ & $24.1 / 1495$ & $22.8 / 1823$ \\
\hline
\end{tabular}

Lastly, Fig. 11 illustrates the cumulative distribution function (CDF) from the turbines' output. It is possible to ascertain the operation of the turbines in the maximum power regime from the colored lines. The Senvion 6.2 turbine would operate more than $65 \%$ of the time, with nearly $6 \%$ under maximum output. Other turbines have periods of activity around 70 and $80 \%$ of time (Fig. 11). These turbines would generate $2 \mathrm{MW}$ or more for $20 \%$ (Vestas 3.3 ), $35 \%$ (Senvion 6.2 ) and $38 \%$ (Vestas 8.0 ) of the time, respectively. These numbers are expected to increase in winter and spring, as the winds are typically stronger during these seasons (Silva et al., 2016, Pimenta et al., 2019). At the Mato Alto base, located $9.3 \mathrm{~km}$ from the BOOA site, the wind remained above the cut-in speed $58 \%$ of the time in the autumn which was lower than that observed here for all the turbines (Mattos, 2016).

\section{Conclusions}

This study evaluated wind profile measurements obtained on a fishing pier located on the southern coast of Santa Catarina, Brazil. A LIDAR was installed on the Ocean and Atmosphere Observation Base (BOOA), loca-

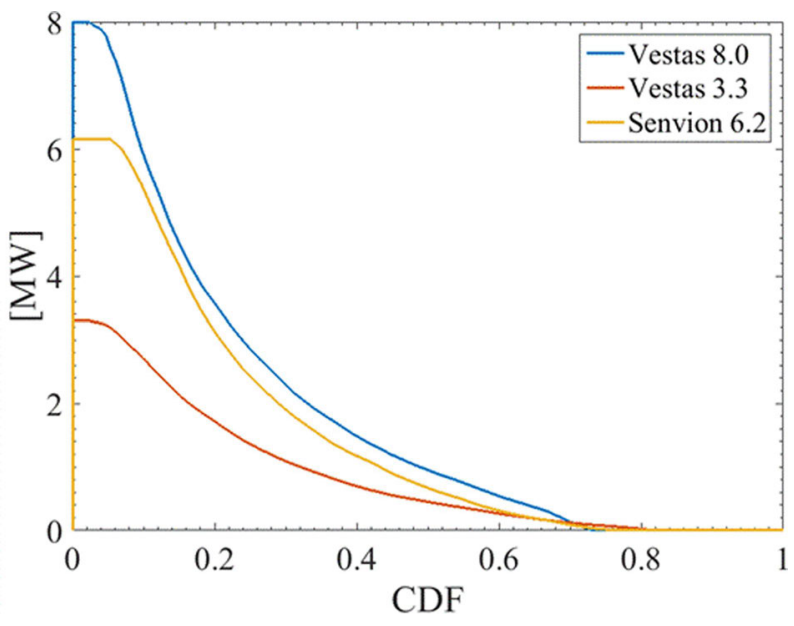

Figure 11 - Cumulative density function distribution for the aerogenerators Vestas 8,0 (blue), Vestas 3.3 (red) and Senvion 6,2 (yellow). ted $250 \mathrm{~m}$ from the beach, making possible wind observations in a transitional region between the oceanic and continental domains.

Low wind shear, high wind magnitudes and large power densities characterized the winds from the oceanic sector. The greatest wind occurrences are for the NE and $\mathrm{SW}$ oceanic sectors, blowing in directions close to the lie of the coastline.

The analysis of the diurnal cycle revealed a strong influence of the breeze circulation. Winds tend to blow from the oceanic sector between 11:00 and 20:00 $\mathrm{h}$ when the sea breeze is strongest, and from the land sector between 22:00 and 09:00 h, when the land breeze dominates. The highest speeds tend to be attained in late afternoon. Vertical shear is minimal between 10:00 and 14:00 $\mathrm{h}$ and maximum during the night and morning. A slight deceleration of winds at higher levels was attributed to the breeze's return circulation.

BOOA profile measurements were compared to the observations made at UFSC Mato Alto, located $9.3 \mathrm{~km}$ inland. Differences in the averaged wind profiles can attain $2.5 \mathrm{~m} \mathrm{~s}^{-1}$. Analyses suggest that turbines in continental areas would be active $58 \%$ of the time, while those in oceanic regions would be operating for up to $80 \%$ of the time. The capacity factor was highest for the smallest simulated turbine, VE3.3, reaching $34.5 \%$ in May, in comparison with values of near $10 \%$ for UFSC Mato Alto. The dataset suggests that significant variations of wind speed and shear should occur in this relatively narrow region of the coastal zone. Turbine arrays could be aligned in the NE-SW direction to minimize wake losses. Hub heights above $90 \mathrm{~m}$ could benefit from the lower wind shear above this height.

The record analyzed was relatively short, which prevents any seasonal characterization. At the same time, this region experiences interanual fluctuations, so that the monthly estimated power and turbine activity are expected to vary from year to year. The LIDAR at BOOA is currently active and more comprehensive studies of the characteristics of its winds will be reported in the future. The laboratory proved to be a versatile option for the monitoring of the wind resources of Brazil's coastline.

\section{Acknowledgments}

We are greatefull to Plataforma de Pesca Entremares crew and Patricia Brandão for all support to BOOA operations. FMP acknowledges CNPq (406801/2013-4, 311930/20166), INCT-INEOF (465672/2014-0) and the European Commission (H2020 Horizon, 828799). ATA acknowledges the support of FAPEMIG (APQ 01575-14) and CNPq (309315/2015-8). We would like to thank EPAGRI/ CIRAM, César Henrique Mattos Pires, Breno Pereira de la Bruna and Gustavo Mohr for the meteorological station and LIDAR maintenance. 


\section{References}

ABBS, D.; PHYSICK, W. L. Sea-breeze observations and modeling. Austr. Meteor. Mag, v. 41, p. 7-19, 1992.

ABEEOLICA. Annual Wind Energy Report. Associação Brasileira de Energia Eólica, ABEEólica, 28 pp. 2018.

AMARANTE, O.A.C.; ZACK, M.B.J.; LEITE DE SÁ, A. Atlas do Potencial Eólico Brasileiro. Centro de Pesquisas de Energia Elétrica (CEPEL), Brasília, Brasil, p. 45, 2001.

ARCHER, C.L.; COLLE, B.A.; MONACHE, L.D.; DVORAK, M.J.; LUNDQUIST, J. et al. Meteorology for coastal/offshore wind energy in the United States: Recommendations and research needs for the next 10 years. Bulletin of the American Meteorological Society, v. 95, n. 4, p. 515-520, 2014.

ARYA, P.S. Introduction to Micrometeorology. Academic Press, San Diego, 420 pp, 2001.

ASSIREU, A.T.; MENDONÇA, J.C.; FREITAS, R.M.; REIS, A.L.; PELLEGRINI, C.C.; PIMENTA, F.M. Uso de VANT para prospecção eólica em sistemas aquáticos: Desenho amostral e avanços instrumentais. Revista Brasileira de Meteorologia, v. 34, n. 2, p. 237-245, 2019.

ASSIREU, A.T.; MENDONÇA, J.C.; FREITAS, R.M.; PASSOS, R.B.; PELLEGRINI, C.C.; PIMENTA, F.M. Escoamento atmosférico sobre uma colina isolada revelado a partir de dados de um veículo aéreo não tripulado (VANT). Revista Brasileira de Meteorologia, v. 34, n. 2, p. 227 236, 2019.

BISCHOFF, O.; WUERTH, I.; CHENG, P.W. Motion effects on LIDAR wind measurement data of the EOLOS buoy. Renewable Energies Offshore, C.G. SOARES (ed.), CRC Press/Taylor and Francis Group, London, p. 197-203, 2015.

CORREA, A.G. Climatologia dos ventos e potencial eólico offshore de Santa Catarina. Dissertação de Mestrado. Programa de Pós-Graduação em Oceanografia, Universidade Federal de Santa Catarina, Florianópolis, Santa Catarina, 2018.

FAPESP. Potencial eólico em terra do Brasil pode ser seis vezes maior do que o estimado. Outubro 2016. Agência FAPESP. Disponível em: http://agencia.fapesp.br/poten cial-eolico-em-terra-do-brasil-pode-ser-seis-vezes-maiordo-que-o-estimado/24053. Acesso em 14/12/2018. 2016.

FRANCHITO, S.H.; ODA, T.O.; RAO, V.B.; KAYANO, M.T. Interaction between coastal upwelling and local winds at Cabo Frio, Brazil: An observational study. Journal of Applied Meteorology and Climatology, v. 47, p. 15901598, 2008.

FRANCHITO, S.H.; RAO, V.B.; STECH, J.L.; LORENZZETTI, J.A. The effect of coastal upwelling on the sea-breeze circulation at Cabo Frio, Brazil: a numerical experiment. Ann. Geophysicae, v. 16, p. 866-881, 1998.

HASAGER, C.B.; STEIN, D.; COURTNEY, M.; PEÑA, A.; MIKKELSEN, T.; STICKLAND, M.; OLDROYD, A. Hub height ocean winds over the North Sea observed by the NORSEWInD Lidar Array: Measuring techniques, quality control and data management. Remote Sensing, v. 5, p. 4280-4303, 2013.

HELMIS, C. et al. Observations of sea-breeze fronts near the shoreline. Boundary-LayerMeteorology, v. 38, n. 4, p. 395-410, 1987.
HOWE, G. Developing a buoy-based offshore wind resource assessment system. Sea Technol Megazine, v. 55, n. 2, p. 41-46, 2014.

KINDLER, D; COURTNEY, M.; OLDROYD, A. Testing and calibration of various LIDAR remote sensing devices for a 2 year offshore wind measurement campaign. In: EWEC 2009 Scientific Proceedings. European Wind. Energy Conference and Exhibition, Marseille, France, p. 141-143, 2009.

KINDLER, D.; ZephIR LIDAR Assessment at the offshore met mast on platform FINO-1. Offshore Certification Report. Windtest Report WT 5256/06, Kaiser-Wilhelm-Koog GmbH, p. 11, 2006.

LI, J.; YU, X.B. Lidar technology for wind energy potential assessment: Demonstration and validation at a site around lake Erie. Energy Conversion and Management, v. 144, p. 252-261, 2017.

LU, X.; MCELROY, M.B.; KIVILUOMA, J. Global potential for wind-generated electricity. Proceedings of the National Academy of Sciences, National Academy of Sciences, v. 106, n. 27, p. 10933-10938, 2009.

MANWELL, J.F.; MCGOWAN, J.G.; ROGERS, A.L. Wind Energy Explained: Theory, Design and Application. John Wiley \& Sons, West Sussex, p. 689, 2010.

MATANO, R.P.; COMBES, V.; PIOLA, A.R.; GUERRERO, R.; PALMA, E.D.; TED STRUB, P.; JAMES, C.; FENCO, H.; CHAO, Y.; SARACENO M. The salinity signature of the cross-shelf exchanges in the southwestern Atlantic Ocean: Numerical simulations, Journal of Geophysical Research, v. 119, p. 7949-7968, 2014.

MATTOS, C. Avaliação do potencial eólico da costa sul catarinense através de um perfilador lidar. Trabalho de Conclusão de Curso. Universidade Federal de Santa Catarina. 2016. $51 \mathrm{pp}$.

MAZZINI, P.L.F.; BARTH, J.A. A comparison of mechanisms generating vertical transport in the Brazilian coastal upwelling regions, Journal of Geophysical Research, v. 118, p. 5977-5993, 2013.

MCTAGGART-COWAN, R.; BOSART, L.F.; DAVIS, C.A.; ATALLAH, E.H.; GYAKUM, J.R.; EMANUEL, K.A. Analysis of Hurricane Catarina (2004). Monthly Weather Review, v. 134, p. 3029-3053, 2006.

MILLER, S.; KEIM, B.D.; TALBOT, R.W.; MAO, H. Sea breeze: Structure, forecasting, and impacts. Reviews of Geophysics, v. 41, n. 3, p. 1-31, 2003.

MÖLLER, O.O.; PIOLA, A.R.; FREITAS, A.C.; CAMPOS, E.J.D. The effects of river discharge and seasonal winds on the shelf off southeastern South America, Continental Shelf Research, v. 28, n. 13, p. 1607-1624, 2008.

NASSIF, F.B. A Tecnologia LIDAR Aplicada a Medições Eólicas Sobre Corpos Hídricos e Oceano. Dissertação de Mestrado. Programa de Pós-Graduação em Engenharia Mecânica, Universidade Federal de Santa Catarina, Florianópolis, Santa Catarina, 2017, 111 pp.

PEÑA, A.; HASAGER, C.B.; GRYNING, S.; COURTNEY, M.; ANTONIOU, I.; MIKKELSEN, T. Offshore wind profiling using light detection and ranging measurements. Wind Energy, v. 12, n. 2, p. 105-124, 2009. 
PIANCA, C.; MAZZINI, P.L.F.; SIEGLE, E. Brazilian offshore wave climate based on NWW3 Reanalysis. Brazilian Journal of Oceanography, v. 58, n. 1, p. 53-70, 2010.

PIMENTA, F.M.; KEMPTON W.; GARVINE, R. Combining meteorological stations and satellite data to evaluate the offshore wind power resource of Southeastern Brazil. Renewable Energy, v. 33, p. 2375-2387, 2008.

PIMENTA, F.M.; SILVA, A.R.; ASSIREU, A.T.; ALMEIDA V.S.; SAAVEDRA, O.R. Brazil offshore wind resources and atmospheric surface layer stability. Energies, v. 12, n. 21, 4195, 2019.

PITTER, M.; SLINGER, C.; HARRIS, M. Introduction of continous-wave doppler LIDAR. In: Remote Sensing for Wind Energy; PEÑA, A., et al. (eds.), DTU Wind EnergyE-Report-0029 (EN); DTU Wind Energy: Roskilde, Denmark, p. 72-103, 2013.

REBOITA, M.S.; GAN, M.A.; ROCHA R.P.; CUSTÓDIO, I. S. Ciclones em superfície nas latitudes Austrais: Parte I Revisão Bibliográfica. Revista Brasileira de Meteorologia, v. 32, n. 2, p. 171-186, 2017.

REBOITA, M.S.; GAN, M.A.; ROCHA, R.P.; AMBRIZZI, T. Regimes de precipitação na América do Sul: uma revisão bibliográfica. Revista Brasileira de Meteorologia, v. 25, n. 2, p. 185-204, 2010.

RODRIGUES, M.L.G.; FRANCO, D; SUGAHARA, S. Climatologia de frentes frias no litoral de Santa Catarina. Revista Brasileira de Geofísica, v. 22, n. 2, p. 135-151, 2004.

SAKAGAMI, Y.; SANTOS, P.A.A.; HAAS, R.; PASSOS, J.C.; TAVES, F.F. Wind shear assessment using wind lidar profiler and sonic $3 \mathrm{~d}$ anemometer for wind energy applications - Preliminary results. In: Renewable Energy in the Service of Mankind Vol I. [S.1.]: Springer, p. 893-902, 2015.

SALVADOR, N.; LORIATO, A.G.; SANTIAGO, A.; ALBUQUERQUE, T.T.A.; REIS JR., N.C.; SANTOS, J.M.; LANDULFO, E.; MOREIRA, G.; LOPES, F.; HELD, G.; MOREIRA, D.M. Study of the thermal internal boundary layer in sea breeze conditions using different parameterizations: application of the WRF model in the greater Vitória region. Revista Brasileira de Meteorologia, v. 31, n. 4, p. 593-609, 2016.
SANTOS, P.A.A. Impacto da Estabilidade Atmosférica no Desempenho de um Pequeno Aerogerador em Terreno Complexo. Dissertação de Mestrado. Programa de PósGraduação em Engenharia Mecânica, Universidade Federal de Santa Catarina, Florianópolis, Santa Catarina, 2014.

SANTOS, P.A.A.; SAKAGAMI, Y.; HAAS, R.; PASSOS, J.C.; TAVES, F.F. Lidar measurements validation under coastal condition. Óptica Pura y Aplicada, v. 48, n. 3, p. 193-198, 2015.

SHIMADA, S.; OHSAWA, T.; OHGISHI, T.; KIKUSHIMA, Y.; KOGAKI, T.; KAWAGUCHI, K.; NAKAMURA, S. Offshore wind profile measurements using a doppler LIDAR at the Hazaki oceanographical research station. In: International Society for Optics and Photonics. International Conference on Optical Particle Characterization (OPC 2014), 2014.

SILVA, A.R.; PIMENTA, F.M.; ASSIREU, A.T.; SPYRIDES, M.H.C. Complementarity of Brazil's hydro and offshore wind power. Renewable and Sustainable Energy Reviews, v. 56, p. 413-427, 2016.

STULL, R. An introduction to Boundary Layer Meteorology. Kluwer Academic Publishers, Netherlands, 1988.

VIANNA, M.L.; MENEZES, V.V.; PEZZA, A.B.; SIMMONDS, I. Interactions between hurricane Catarina (2004) and warm core rings in the south Atlantic Ocean, Journal of Geophysical Research, v. 115, C07002, p. 1-19, 2010.

WAGNER, R; MIKKELSEN, T; COURTNEY, M. Investigation of turbulence measurements with a continuous wave, conically scanning LIDAR. In: European Wind Energy Conference and Exhibition 2009, European Wind Energy Conference and Exhibition, Marseille, France, v. 6, p. 3740-3749, 2009.

WISSEMANN, C. Offshore Wind Energy Meeting Presentation. Rutgers University, IOOS, n. Feb, 2009.

ZEPHIR LIDAR. Zephir 300 operations \& maitenance manual v3.7. Zephir Ltd., England, p. 64, 2014.

License information: This is an open-access article distributed under the terms of the Creative Commons Attribution License (type CC-BY), which permits unrestricted use, distribution and reproduction in any medium, provided the original article is properly cited. 